\title{
Dilated cardiomyopathy and severe heart failure. An update for pediatricians
}

\author{
Paola Caviedes Bottner, M.D., ${ }^{a}$ Tamara Córdova Fernández, M.D., ${ }^{a}$ \\ Marcos Larrain Valenzuela, M.D., ${ }^{b}$ and Pablo Cruces Romero, M.D. ${ }^{a, c}$
}

\begin{abstract}
Dilated cardiomyopathy is the main cause of heart failure leading to heart transplant. Its prognosis is variable and depends on the etiology, the patient's age at onset, and the severity. The management of dilated cardiomyopathy is aimed at minimizing symptoms and preventing disease progression; it requires a comprehensive screening for comorbidities and the prevention of complications to improve the overall status of these children and mitigate their prognosis. Here we present a review oriented at the multidisciplinary management that pediatricians should consider when seeing these patients.

Key words: dilated cardiomyopathy, heart failure, treatment, prognosis, pediatrics.
\end{abstract}

http:/ / dx.doi.org/10.5546/aap.2018.eng.e421

To cite: Caviedes Bottner P, Córdova Fernández T, Larraín Valenzuela M, et al. Dilated cardiomyopathy and severe heart failure. An update for pediatricians. Arch Argent Pediatr 2018;116(3):e421-e428.

a. Pediatric Critical Care Unit. Hospital El Carmen de Maipú.

b. Department of Pediatric Cardiology. Hospital El Carmen de Maipú.

c. Centro de Investigación de Medicina Veterinaria, Escuela de Medicina

Veterinaria, Facultad de Ecología y

Recursos Naturales, Universidad Andres Bello.

Santiago, Chile.

E-mail address:

Tamara Córdova

Fernández, M.D.:

tamara_cor@hotmail.com

Funding:

None.

Conflict of interest:

None.

Received: 3-27-2017

Accepted: 10-18-2017

\section{GLOSSARY}

ACE: angiotensin-converting enzyme.

ADH: antidiuretic hormone.

ATP: adenosine triphosphate.

BNP: brain natriuretic peptide.

BP: blood pressure.

CNS: central nervous system.

CO: cardiac output.

DCM: dilated cardiomyopathy.

EF: ejection fraction.

HF: heart failure.

HLA: human leukocyte antigen.

IL: interleukin.

NF-kB: Nuclear factor kappa beta.

LV: left ventricle.

LVSF: left ventricle shortening fraction.

RAA: renin-angiotensin-aldosterone.

RNA: ribonucleic acid.

SVR: systemic vascular resistance.

TH: T helper cells.

TNF: tumor necrosis factor.

\section{INTRODUCTION}

DCM is a progressive and almost always irreversible disease of the heart muscle, characterized by left ventricle dilation and a reduced systolic function, leading to $\mathrm{HF}$ and, later, to multiple organ failure, with a $20 \%$ mortality rate at 1 year and a 56\% mortality rate at 4 years, so it is the main indication for heart transplant in children and adults. ${ }^{1,2}$ The symptoms of DCM are non-specific (fatigue, dyspnea on exertion, and edema), thus hindering the possibility of making an early diagnosis; the actual incidence of DCM has been estimated at 0.57 cases per 100000 persons / year. ${ }^{3,4}$ DCM has different stages (latent, established, advanced) and it may be approached with various treatments. This review will focus on the multidisciplinary management of advanced DCM. ${ }^{5}$

\section{ETIOLOGY}

The etiology of DCM is varied; in children the main causes are disorders. However, a cause may not be found in up to $70 \%$ of cases, so idiopathic DCM is the most common presentation and the diagnosis is one of exclusion. ${ }^{6,7}$ Among the identifiable causes, myocarditis and arrhythmias may show functional improvement with a timely treatment ${ }^{9,13}$ (Table 1).

DCM is more common among younger infants, males (x-linked and mitochondrial inheritance), and black people. ${ }^{14}$

\section{Pathogenesis and compensation mechanisms}

In DCM, the heart shows an adaptive response with a diffuse lesion characterized by cardiomyocyte stiffness and fibrosis, hypertrophic myocarditis and neuromuscular 
and atrophic cell interposition, glycogen storage, abnormal mitochondria, and myosin, actin, troponin, and troponin $\mathrm{T}$ reduction or absence. ${ }^{15-17}$ In specific etiologies, such as post-infection DCM, there is also an increase in inflammatory infiltrate where TH1 and TH2 cells may be responsible for the perpetuation of inflammation. ${ }^{18-20}$ Some viruses that introduce RNA into the myocardial cell may

TABLE 1. Etiology of dilated cardiomyopathy during childhood

\begin{tabular}{|c|c|c|}
\hline Etiological groups & Subgroups & \\
\hline Infections & $\begin{array}{l}\text { Bacterial } \\
\text { Fungal } \\
\text { Protozoan } \\
\text { Spirochete }\end{array}$ & $\begin{array}{l}\text { Group A and B coxsackievirus } \\
\text { Echovirus } \\
\text { Adenovirus } \\
\text { Mumps } \\
\text { Rubella } \\
\text { Streptococcus and Staphylococcus } \\
\text { Salmonella } \\
\text { Neisseria } \\
\text { Mycobacterial, mycoplasma, and Chlamydia } \\
\text { Candida } \\
\text { Aspergillosis } \\
\text { Trypanosoma cruzi } \\
\text { Toxoplasmosis } \\
\text { Lyme disease }\end{array}$ \\
\hline Metabolic & $\begin{array}{l}\text { Endocrine } \\
\text { Storage diseases } \\
\text { Nutritional deficiency } \\
\text { Hypertaurinuria }\end{array}$ & $\begin{array}{l}\text { Hypo-/hyperthyroidism } \\
\text { Diabetes mellitus and born to a diabetic mother } \\
\text { Pheochromocytoma } \\
\text { Neuroblastoma } \\
\text { Congenital adrenal hyperplasia } \\
\text { Glycogen storage } \\
\text { Mucopolysaccharidosis } \\
\text { Sphingolipidosis } \\
\text { Hemochromatosis } \\
\text { Kwashiorkor } \\
\text { Carnitine }\end{array}$ \\
\hline Systemic & $\begin{array}{l}\text { Connective tissue system } \\
\text { Infiltrations and granulomas } \\
\text { Others }\end{array}$ & $\begin{array}{l}\text { Lupus erythematosus } \\
\text { Juvenile rheumatoid arthritis } \\
\text { Polyarteritis nodosa } \\
\text { Kawasaki disease } \\
\text { Pseudoxanthoma } \\
\text { Leukemia } \\
\text { Sarcoidosis } \\
\text { Amyloidosis } \\
\text { Hemolytic uremic syndrome } \\
\text { Reye syndrome } \\
\text { Mitochondrial disease }\end{array}$ \\
\hline Genetic & $\begin{array}{l}\text { Muscular dystrophies and myopathies } \\
\text { Neuromuscular disorders } \\
\text { Gene mutations } \\
\text { of cardiac structural proteins }\end{array}$ & $\begin{array}{l}\text { Duchenne muscular dystrophy } \\
\text { Steinert muscular dystrophy and Barth syndrome } \\
\text { X-linked cardiomyopathy } \\
\text { Progressive juvenile spinal muscular atrophy } \\
\text { Myotubular myopathy } \\
\text { Friedreich's ataxia } \\
\text { Sarcomere, cytoskeleton, desmosome } \\
\text { sarcoplasmic reticulum, nucleus, mitochondrion, } \\
\text { extracellular matrix,and ion channels }\end{array}$ \\
\hline Toxic & Drugs & $\begin{array}{l}\text { Sulfa drugs } \\
\text { Penicillins } \\
\text { Anthracyclines }\end{array}$ \\
\hline Tachyarrhythmias & $\begin{array}{l}\text { Supraventricular tachycardia } \\
\text { Atrial fibrillation } \\
\text { Ventricular tachycardia }\end{array}$ & \\
\hline
\end{tabular}

References: ${ }^{5-13}$. 
be capable of causing an autoimmune response induced by myocardial epitope recognition and inducing cardiomyocyte apoptosis. At the same time, an increase has been observed in plasma proinflammatory cytokines (IL- 6 and TNF- $\alpha$ ), directly associated with cardiomyocyte remodeling, a reduced myocardial contractility, and ventricular dilation..$^{21-23}$

In the early stages of DCM, LV remodeling is an adaptive response that compensates for reduced contractility. However, over time, the LV becomes dilated and turns dysfunctional, which leads to an antegrade failure with peripheral hypoperfusion and to retrograde failure with lung edema and venous congestion, which are responsible for symptoms, and ends in HF, the main cause of death.

The main compensation and underlying mechanisms, together with early and late symptoms, are detailed in Table 2 . The activation of the sympathetic nervous system helps to maintain an adequate $\mathrm{CO}$ in the case of a mild to moderate reduction in ejection volume; therefore, the recommendation is that any drug capable of suppressing such response should be used cautiously, e.g., systemic anesthetic agents, which in the long term induce a $60-70 \%$ decrease in $\beta 1$-receptor expression and a reduced response to $\beta 2$-receptors ${ }^{24,25}$ (see below). In addition, prostaglandin levels rise and maintain renal blood flow and locally antagonize the effects of $\mathrm{ADH}$; therefore, it is advisable to use nonsteroidal anti-inflammatory drugs with caution. Other mechanisms that have also been described include an increased atrial natriuretic peptide level, which stimulates diuresis, an increased BNP level, which is responsible for myocardial hypertrophy, and kinin-kallikrein system activation, which induces renal vasodilatation. ${ }^{26}$

\section{Diagnostic suspicion}

Symptoms may be non-specific because they may simulate a respiratory disease. The diagnostic suspicion is higher when tachycardia and HF symptoms and signs are detected. A chest $X$-ray screens for an enlarged cardiac silhouette, and subsequent $X$-rays may show the transition from oligemia to pulmonary congestion. An electrocardiogram and a cardiac enzyme test may be requested, and an echocardiogram is confirmatory. The cardiologist may complement this procedure with magnetic resonance imaging, coronary catheterization or other tests. ${ }^{27}$

\section{Clinical and echocardiographic prognostic factors}

Some clinical factors are associated with a higher mortality, such as diagnosis in children younger than 14.3 years, established $\mathrm{HF}^{27,28}$

TABLE 2. Compensation mechanisms of heart failure

\begin{tabular}{|c|c|c|c|}
\hline Mechanism & Mediators & Short-term effects & Long-term effects \\
\hline \multirow[t]{2}{*}{ Ventricular hypertrophy } & $\begin{array}{l}\text { RAA axis } \\
\text { ADH }\end{array}$ & Water and sodium retention & $\begin{array}{l}\text { Increased blood volume } \\
\text { Increased BP }\end{array}$ \\
\hline & Endothelin & Increased contractility & $\begin{array}{c}\text { Increased } \mathrm{HR} \\
\text { Enlarged myocardial mass } \\
\text { Increased } \mathrm{O}_{2} \text { consumption }\end{array}$ \\
\hline \multirow[t]{2}{*}{ Ventricular dilation } & RAA axis & Water and sodium retention & Increased blood volume \\
\hline & $\mathrm{ADH}$ & & Increased BP \\
\hline \multirow[t]{3}{*}{ Adrenergic stimulation } & $\begin{array}{l}\text { Noradrenaline } \\
\text { Dopamine }\end{array}$ & $\begin{array}{c}\text { Peripheral } \\
\text { venoconstriction }\end{array}$ & Blood volume \\
\hline & Adrenaline & Increased contractility & $\begin{array}{c}\text { Reduced } \beta 1 \text {-receptors } \\
\text { Reduced } \beta 2 \text {-receptor response }\end{array}$ \\
\hline & & SVR & $\begin{array}{l}\text { Increased BP } \\
\text { Arrhythmias }\end{array}$ \\
\hline
\end{tabular}

RAA: renin-angiotensin-aldosterone; $\mathrm{ADH}$ : antidiuretic hormone; $\mathrm{BP}$ : blood pressure; HR: heart rate;

SVR: systemic vascular resistance; $\mathrm{O}_{2}$ : oxygen.

References: ${ }^{21-26}$. 
nutritional status, and carnitine deficiency. Other factors are associated with a higher morbidity, such as vitamin D deficiency and anemia, which are detailed below.

The echocardiography is used to confirm diagnosis and assess disease severity and progression. EF, LVSF, end-systolic and enddiastolic LV dimensions, and their corresponding Z-scores are used as prognostic factors. A study showed that children with an EF $<35 \%$ had a $50 \%$ survival rate at 4 years versus $90 \%$ in children with a higher EF. When comparing patients with DCM and severe HF, the mean LVSF of deceased patients was $12 \%$ versus $21 \%$ among survivors. ${ }^{28}$ Another study determined that an end-diastolic LV dimension with a Z-score $>7.7$ and a LV flow propagation velocity with a Z-score $>-0.28$ were predictors of disease progression. ${ }^{27-30}$

Elevated biomarkers, such as atrial natriuretic peptide and BNP, are considered as poor prognostic factors, even in asymptomatic patients, and a direct correlation has been observed with the echocardiographic dimension used during the cardiological follow-up of these patients: enddiastolic LV measurement, isovolumic contraction time of the LV, Tei index, and M-mode assessment of the interventricular septum diameter in systole and diastole. ${ }^{27}$

It has also been observed that, although less specific than DCM, an increase in uric acid and procalcitonin levels may correlate with a poor prognosis, especially among patients with pulmonary hypertension. ${ }^{27}$

\section{Comprehensive management of patients with dilated cardiomyopathy}

Most of the times, there is no etiological treatment for DCM, so its management is aimed at relieving symptoms, delaying heart failure, and prolonging survival. However, it has a $40 \%$ failure rate at 2 years and may lead to refractory HF requiring heart transplant.

Pharmacological support is based on ACE inhibitors, diuretics, beta-blockers, digitalis, and anticoagulants. These should be accompanied by a complete multidisciplinary assessment, as detailed below.

\section{a) Nutritional care}

Malnutrition is an independent marker of mortality and morbidity in children and adolescents with DCM and HF, and has been associated with frequent hospitalizations, growth retardation, and poor post-transplant outcomes. ${ }^{31}$ There is a risk for energy imbalance and malnutrition given the high energy output and low food intake.

Structural and functional gastrointestinal alterations may be observed as causes of malnutrition. Structural alterations include changes in the gastric mucosa, intestinal wall edema, and increased collagen levels in the small intestine. Functional changes are caused by intestinal hypoperfusion, which leads to an alteration in protein transport, a high rate of bacterial colonization, and endotoxin absorption. In the long term, a reduced intestinal absorption and nutrient loss occur. ${ }^{32}$

In addition, malnutrition contributes to myocardial dysfunction, endothelial dysfunction, musculoskeletal atrophy, insulin resistance, and lipolysis. Therefore, it is critical for pediatricians to understand metabolism and the ways in which children may achieve a comprehensive development.

Volume restriction is an important barrier with few nutritional alternatives. An optimal nutritional support means not only meeting energy output but also macro- and micronutrient requirements. To this end, concentrated infant formula or high-calorie additives are used, but they provide a smaller protein intake which may result in muscle breakdown. To avoid this, the recommendation is to provide a protein intake of $1.5-2.5 \mathrm{~g} / \mathrm{kg}$ for infants and $0.8-1.5 \mathrm{~g} / \mathrm{kg}$ for older children. An early strategy aimed at reducing energy output is the placement of an enteral feeding tube. Continuous enteral feeding is usually done during the night so as to avoid interference with the patient's routine. ${ }^{33}$

Nutritional assessment is not easy. Weight estimation is limited by fluid changes, even during the day, and the use or not of diuretics. The measurement of skinfolds, including the triceps, and arm circumference may not be useful to estimate lean body mass because they are altered in the presence of edema. For this reason, it is necessary to perform a complementary assessment of biochemical markers, such as albumin, prealbumin, transferrin, transferritin, retinalbinding protein, and C-reactive protein. It has been observed that patients with an albumin level below $3 \mathrm{~g} / \mathrm{dL}$ have a longer length of stay, regardless of the cause of hospitalization. In addition, patients with a higher blood albumin level showed lower BNP values and lower inotrope use during their hospital stay. ${ }^{34-36}$

Children with chronic diseases and an 
increased inflammatory cytokine level have growth hormone resistance, so nutritional status and cytokine levels are the main determinants of such resistance. Proinflammatory cytokines, such as TNF- $\alpha$, act on the CNS by altering appetite and energy metabolism and provide a signal that causes the loss of muscle mass (nuclear factor $\kappa \mathrm{B}$ and ATP-dependent ubiquitin proteolytic pathways). A poor calorie and protein intake may interfere during a critical growth period and is irreversible, especially if it started during puberty. Cytokines seem to alter gonadotropinreleasing hormone secretion and its ability to have an endogenous response to testosterone, thus worsening the effects of malnutrition and delaying pubertal development. ${ }^{37}$

When DCM is caused by metabolic errors, such as beta-oxidation defects and mitochondrial diseases, intermediate organic acids accumulate and, once they conjugate with L-carnitine, may be excreted in urine. Therefore, L-carnitine supplementation is the cornerstone of treatment. ${ }^{38,39}$ In addition, its use in children with HF improves their nutritional status, with an increased lean body mass, EF, and LV surface area, probably secondary to an enhanced performance of non-hypertrophic cardiomyocytes, which compensate for this by exerting a higher contractile force. . $^{40-42}$

Vitamin D is not only responsible for calcium absorption but also for an adequate immune performance and cell proliferation. Cardiomyocytes have vitamin $\mathrm{D}$ receptors that are directly involved in contractility, without calcium interaction. Children with heart disease are at a higher risk for vitamin D deficiency. Although some studies had contradictory results, vitamin $\mathrm{D}$ deficiency has been related to higher inotrope requirements, a longer length of stay, a higher risk for infections, and an unstable fluid management. ${ }^{43-46}$ Supplementation for 12 months with $1000 \mathrm{U} /$ day of cholecalciferol in children with HF and DCM or other systolic LV dysfunction reduces inflammation markers and improves LV dimensions and the index of systolic function. ${ }^{47}$

\section{b) Physical activity}

The combination of a poor nutritional status and immunological activation may induce skeletal muscle abnormalities, a reduced physical ability, and a worsened quality of life. Lack of physical activity induces a loss of muscle mass and worsens malnutrition, so the recommendation is to encourage physical activity and maintain a range of motion in accordance with the patient's cardiovascular condition. ${ }^{48}$

\section{c) Blood products}

Iron deficiency anemia is frequent due to poor iron intake, malabsorption, intestinal loss, abnormal red blood cells, renal involvement, chronic inflammation, hemodilution, and chronic drug use. Based on such varied causes, it is critical to provide oral or intravenous iron supplementation.

In the case of potential transplant receptors, it is suggested to limit the exposure to transfusions because they are considered a risk factor for the development of anti-HLA antibodies in relation to allograft rejection. ${ }^{49}$

\section{d) Anesthetic considerations}

These patients are more prone to have severe hypotension following the administration of sedative and anesthetic agents, either because of their underlying disease or the use of vasodilators (ACE inhibitors, beta-blockers). The use of anesthetic agents causes venodilation and a resulting decrease in preload, which may accentuate hypovolemia. Therefore, even if vital signs are recorded to be in the normal range, using inotropes before a procedure that requires sedation may notably reduce the drop in CO. In general, hospitalized patients have a higher risk for severe hypotension than outpatients. ${ }^{50}$

The most commonly used agents for sedation/anesthesia in patients with DCM are propofol, ketamine, thiopental, and etomidate. Propofol and thiopental have a dose-dependent hypotensive effect and cause a sudden decrease of preload and postload, and even myocardial contractility. Besides, ketamine increases heart rate and $\mathrm{BP}$ in the normal heart, but it may also induce myocardial depression in these patients, secondary to catecholamine depletion. Patients with cardiomyopathy and end-stage HF have shown a decrease in postload that results in hypotension, together with a higher risk for ischemia, arrhythmias, and cardiac arrest. It has not been demonstrated that etomidate reduces contractility, but it does reduce cortisol levels and suppresses the adrenal response to stress. Still, it is recommended for patients with end-stage HF because the relative risk for severe hypotension is lower than that of other anesthetic agents. ${ }^{51-53}$

High-dose opioids alter heart function and have a smaller response to stress, especially 
during surgical procedures; morphine is the most widely known drug used to decrease preload and/or SVR. The combined use of opioids and benzodiazepines doubles the risk for circulatory depression. ${ }^{53,54}$

Anesthetic gases suppress contractility and reduce SVR, which makes CO dependent only on preload and vasoactive drug use. Nitrous oxide seems to have little effect on SVR. Based on the risk for complications, it has been suggested that patients with HF and a LVSF $<25 \%$ should be hospitalized before undergoing an anesthetic procedure because there is a 38\% risk for vasoactive support requirement. . $^{5-57}$

\section{e) New therapies}

In patients with histological evidence of active chronic inflammation, the use of immunoglobulins and interferon-beta improve EF and functional capacity. ${ }^{58,59}$

Doing genetic tests in family members of patients with DCM or muscular dystrophy may help to make an early diagnosis and eventually administer treatment to prevent myocardial fibrosis and remodeling. ${ }^{5}$

The high cost of a transplant makes it necessary to look for other alternatives. In this regard, the use of stem cells has been proposed as a potential and innovative approach that promotes cardiac regeneration by replacing injured tissue. The largest clinical trial included 9 children with DCM, where 5 showed an improvement in functional capacity, reduced BNP levels, and a better contractility. Among these 5 patients, 3 did not make it to the transplant. ${ }^{60,61}$ Further studies are necessary to establish their role.

\section{f) Immunizations}

Patients with HF have a higher risk for hospitalization because they tend to have decompensations triggered by a lack of treatment adherence, myocardial ischemia, and respiratory infections. Considering that pulmonary congestion is a predisposing factor for respiratory infections, the heart associations of North America, South America, and Europe have recommended to administer the palivizumab vaccine to infants younger than 1 year old and the influenza and Streptococcus pneumoniae vaccines to all children with DCM so as to maximize immunization coverage. ${ }^{62}$

\section{g) Psychosocial considerations}

Another aspect to be taken into account is the management and acknowledgementof emotional alterations. These patients usually have anxiety and fears typical of a terminal illness. They and their families require psychological counseling to address symptom progression, diagnosis, treatment, and prognosis. The objective is to identify irrational thoughts about their disease and normalize emotions as they are expressed. In addition, psychosocial disorders should be suspected and identified so that patients are referred for treatment in a timely manner. The subsequent stages and the emergence of new complications typical of immunosuppression after a transplant should be addressed so that patients and their families have the necessary tools to deal with them.

\section{REFERENCES}

1. Daubeney P, Nugent A, Chondros P, et al. National Australian Childhood Cardiomyopathy Study. Clinical featuresand outcomes of childhood dilated cardiomyopathy: results from a national population-based study. Circulation 2006;114()24:2671-8.

2. Naudi D, Rossano JW. Epidemiology and Cost of heart failure in children. Cardiol Young 2015;25(8):1460-8.

3. Towbin JA, Lowe AM, Colan SD, et al. Incidence, causes, and outcomes of dilated cardiomyopathy in children. JAMA 2006;296(15):1867-76.

4. Nugent AW, Daubeney PEF, Chondros P, et al. The epidemiology of childhood cardiomyopathy in Australia. N Eng J Med 2003;348(17):1639-46.

5. Japp AG, Gulati A, Cook SA, et al. The Diagnosis and Evaluation of Dilated Cardiomyopathy. J Am CollCardiol 2016;67(25):2996-3010.

6. Bostan OM, Cil E. Dilated cardiomyopathy in childhood: prognostic features and outcome. ActaCardiol 2006; 61(2):169-74.

7. ElliottP, Andersson B, Arbustini E, et al. Classification of the cardiomyopathies: a position statement from the European Society of Cardiology Working Group on Myocardial an pericardial diseases. Eur Heart J 2009;29(2):270-6.

8. Prasad AN, Chaudhary S. Intravenous immunoglobulin in children with acute myocarditis and/or early dilated cardiomyopathy. Indian Pediatr 2014;51(7):583-4.

9. Ono M, Shimizu J, Miyachi $Y$, et al. Control of autoimmune myocarditis and multiorgan inflammation by glucocorticoid-induced TNF receptor family-related protein(high), Foxp3-expressing CD25+ and CD25regulatory T cells. J Immunol 2006;176(8):4748-56.

10. Sakaguchi S. Regulatory T cells: key controllers of immunologic self-tolerance. Cell 2000;101(5):455-8.

11. Carlquist J, Menlove R, Murray M, et al. HLA class II (DR and DQ) antigen associations in idiopathic dilated cardiomyopathy: validation study and meta-analysis of published HLA association studies. Circulation 1991;83(2):515-22.

12. Anderson JL, CarlquistJF, Hammond EH. Deficient natural killer cell activity in patients with idiopathic dilated cardiomyopathy. Lancet 1982;2(8308):1124-7. 
13. Gerli R, Rambotti P, Spinozzi F, et al. Immunologic studies of peripheral blood from patients with idiopathic dilated cardiomyopathy. Am Heart J 1986;112(2):350-5.

14. Gagliardi MG. Dilated cardiomyopathy in children. ActaPaediatrSuppl 2006;95(452):14-6.

15. Sparks E, Boudoulas K, Raman S, et al. Heritable cardiac conduction and myocardial disease: from the clinic to the basic science laboratory and back to the clinic. Cardiology 2011;118(3):179-86.

16. Matitiau A, Perez-Atayde A, Sanders SP, et al. Infantile dilated cardiomyopathy: relation of outcome to left ventricular mechanics, hemodynamics and histology at the time of presentation. Circulation 1994;90(3):1310-8.

17. Balestrini L. Miocardiopatia Dilatada en niños. CardiologíaPediátrica. [Accessed on: November 10 $0^{\text {th }}, 2016$ ]. Available at: www.fac.org.ar/tcvc/llave/c178/bales.htm.

18. Cooper LT. Myocarditis. N Engl J Med 2009;360(15):1526-38.

19. Fairweather D, Frisancho-Kiss S, Rose N. Viruses as adjuvants for autoimmunity:evidencefrom Coxsackievirusinduced miocarditis. Rev Med Virol 2005;15(1):17-27.

20. San Martin M, García A, Rodríguez F. Autoinmunidad y miocardiopatía dilatada: situación actual y perspectivas. Rev EspCardiol 2002;55(5):514-24.

21. Barranco Ruiz F, Blasco Morilla J, Mérida Morales A, et al eds. Insuficiencia Cardiaca. In: Principios de Urgencias, Emergencia y Cuidados críticos. Granada: Alhulia, 1999.

22. Moruno A, García-Angleu F, Coserria F. Miocardiopatías en la infancia. An PediatrContin 2007;5(2):77-84.

23. Towbin J, Lowe A, Colan S, et al. Incidence, causes, and outcomes of dilated cardiomyopathy in children. JAMA 2006;296(15):1867-76

24. Fisiopatología de la Insuficiencia Cardiaca. Apuntes de Fisiopatología Cardiovascular (re-edición 2011). [Accessedon: October 24 $4^{\text {th }}, 2017$ ]. Available at: https:// www.cardiouc.cl/CardiologiaUC/curso_iii/ apuntes $\% 20$ 3ro $\% 202011 /$ 004FISIOPATOLOGIA $\% 20$ DE $\% 20$ LA $\% 20$ INSUFICIENCIA $\% 20$ CARDIACA.doc

25. Griffin ML, Hernandez A, Martin TC, et al. Dilated cardiomyopathy in infants and children. J Am CollCardiol 1988;11(1):139-44.

26. Guadalajara Boo J. Entendiendo la Insuficiencia cardiaca. Arch CardiolMex 2006;76(4):431-47.

27. Mathew T, Williams L, Navaratnam G, et al. Diagnosis and assessment of dilated cardiomyopathy: a guideline protocol from the British Society of Echocardiography. Echo Res Pract2017;4(2):G1-13.

28. Kaddourah A, Goldstein S, Lipshultz S, et al. Prevalence, Predictors, and Outcome of Cardiorenal Syndrome in Children with Dilated Cardiomyopathy. A report from the pediatric cardiomyopathy registry. PediatrNephrol 2015;30(12):2177-88.

29. Richardson $P, M c K e n n a W$, Bristow $M$, et al. Report of the 1995 World Health Organization/International society and Federation of Cardiology task force on the Definition an classification of the Cardiomyopathies. Circulation 1996;93(5):841-2.

30. Molina KM, Shrader P, Colan SD, et al. Pedictors of Disease Progression in Pediatric Dilated Cardiomyopathy. Circ Heart Fail 2013:6(6);1214-22.

31. Azevedo VM, AlbanesiFilho FM, Castier MB, et al. O Impacto da desnutriçãona cardiomiopatía dilatada idiopática nainfância. J Pediatr (Río J) 2004;80(3):211-6.

32. Romeiro F, Okoshi K, Zornoff L, et al. Alteraciones gastrointestinales asociadas a Insuficiencia Cardiaca. Arq Bras Cardiol 2012;98(3):273-7.

33. Wong S, Cheifetz, Ong C, et al. Nutrition Support for Children Undergoing Congenital Heart Surgeries: A Narrative Review. World J PediatrCongenit Heart Surg
2015;6(3):443-54.

34. Ong C, Han WM, Wong JJ, et al. Nutrition biomarkers and clinical outcomes in critically ill children: a critical appraisal of the literature. ClinNutr 2014;33(2):191-7.

35. Leite HP, Fisberg M, de Carvalho WB, et al. Serum albumin and clinical outcome in pediatric cardiac surgery. Nutrition 2005;21(5):553-8.

36. Radman M, Mack R, Barnoya J, et al. The effect of preoperative nutritional status on postoperative outcomes in children undergoing surgery for congenital heart defects in San Francisco (UCSF) and Guatemala City (UNICAR). J ThoracCardiovascSurg 2014;147(1):442-50.

37. KyleUG,Shekerdemian LS, Coss-BuJA. Growth Failure and Nutrition Considerations in Chronic Childhood Wasting Diseases. NutrClinPract 2015;30(2):227-38.

38. Helton E, Darragh R, Francis P, et al. Metabolic aspects of myocardial disease and a role for L-carnitine in the treatment of childhood cardiomyopathy. Pediatrics 2000;105(6):126070.

39. Winter S, Jue K, Prochazka J, et al. The role of L-carnitine in pediatric cardiomyopathy. J Child Neurol1995;10(Suppl 2):S45-51.

40. Azevedo VM, AlbanesiFilho M, Castier M, et al. O Impacto da L-carnitina nos parâmetrosecocardiográficos da cardiomiopatía dilatada nainfância. Rev Socerj 2005;18(Suppl A):S100-4.

41. Azevedo VM, Albanesi FM, Santos MA, et al. The role of L-carnitine in nutritional status and echocardiographic parameters in idiopathic dilated cardiomyopathy in children. J Pediatr 2005;81(5):368-72.

42. Pauly DF, Pepine CJ. The role of carnitine in myocardial dysfunction. Am J Kidney Dis 2003;41(4 Suppl 4):S35-43.

43. Venkatrans S, Chillinuri S, Adrish M, et al. Vitamin D deficiency is associated with mortality in the medical intensive care unit. Crit Care 2011;15(6):R292.

44. Braun AB, Gibbons KF, Litonjua AA, et al. Low serum 25-hydroxyvitamin $D$ at critical care initiation is associated with increased mortality. Crit Care Med 2012;40(1):63-72.

45. Higgins DM, Wischmeyer PE, Queensland KM, et al. Relationship of vitamin D deficiency to clinical outcomes in critically ill patients. JPEN J Parenter Enteral Nutr 2012;36():713-20

46. Rey C, Sánchez-Arango D, López-Herce J, et al. Vitamin D deficiency at pediatric intensive care admission. J Pediatr (Rio J) 2014;90(2):135-42.

47. Abou-ZahrR,KaudilSB. A pediatric critical care perspective on Vitamin D. Pediatr Res 2015;77(1-2):164-7.

48. Martinez P, Okoshi K, Zornoff, et al. Chronic heart failure induced skeletal muscle atrophy, necrosis, and changes in myogenic regulatory factors. Med SciMonit 2010;16(12):BR374-83.

49. Thrush P, Hoffman T. Pediatric heart transplantationindications and outcomes in the current era. J Thorac Dis 2014;6(8):1080-96.

50. Rosenthal DN, Hammer GB. Cardiomyopathy and heart failure in children: anesthetic implications. Pediatr Anaesth 2011;21(5):577-84.

51. Kudoh A, Matsuki A. Ketamine inhibits inositol 1,4,5-trisphosphate production depending on the extracellular $\mathrm{Ca} 2+$ concentration in neonatal rat cardiomyocytes. AnesthAnalg 1999;89(6):1417-22.

52. Williams GD, Philip BM, Chu LF, et al. Ketamine does not increase pulmonary vascular resistance in children with pulmonary hypertension undergoing sevoflurane anesthesia and spontaneous ventilation. AnesthAnalg 2007;105(6):1578-84.

53. Sprung J, Ogletree-Hughes ML, Moravec CS. The effects of etomidate on the contractility of failing and nonfailing 
human heart muscle. AnesthAnalg 2000;91(1):68-75.

54. Rivenes SM, Lewin MB, Stayer SA, et al. Cardiovascular effects of sevoflurane, isoflurane, halothane, and fentanylmidazolam in children with congenital heart disease: an echocardiographic study of myocardial contractility and hemodynamics. Anesthesiology 2001;94(2):223-9.

55. Ikemba CM, Su JT, StayerSA, et al. Myocardial performance index wit sevoflurane-pancuronium versus fentanylmidazolam-pancuronium in infants with a functional single ventricle. Anesthesiology 2004;101(6):1298-305.

56. Kipps AK, Ramamoorthy CR, RosenthalDN, etal. Children with cardiomyopathy: complications after noncardiac procedures with general anesthesia. PediatrAnaesth 2007;17(8):775-81.

57. Wong G, Morton N. Total intravenous anesthesia (TIVA) in pediatric cardiac anesthesia. Pediatr Anaesth 2011;21(5): 560- 6 .
58. Frustad A, Russo MA, Chimenti C. Randomized study on the efficacy of immunosuppressive therapy in patients with virus-negative inflammatory cardiomyopathy: the TIMIC study. Eur Heart J 2009;30(16):1995-2002.

59. Kühl U, Pauschinger M, Schwimmbeck PL, et al. Interferonbeta treatment eliminates cardiotropic viruses and improves left ventricular function in patients with myocardial persistence of viral genomes and left ventricular dysfunction. Circulation 2003;107(22):2793-8.

60. Rupp S, Jux C, Bönig H, et al. Intracoronary bone marrow cell application for terminal heart failure in children. Cardiol Young 2012;22(5):558-63.

61. Selem SM,KaushalS,HareJ.Stem Cell Therapy for Pediatric Dilated Cardiomyopathy. CurrCardiol Rep 2013;15(6):369-89.

62. Martins W, Ribeiro M, de Oliveira L, et al. Vacunación contra Influenza y Neumococo en la Insuficiencia Cardiaca - Una recomendación poco aplicada. Arq Bras Cardiol 2011;96(3):240-5. 